\title{
PENGARUH MOTIVASI KERJA DAN DISIPLIN KERJA TERHADAP KINERJA PEGAWAI PADA PT PINUS MERAH ABADI SINGARAJA
}

\author{
K. K. S. B. Bagaskara ${ }^{1}$, K. K. Heryanda ${ }^{2}$ \\ 1,2 Jurusan Manajemen, Universitas Pendidikan Ganesha, Singaraja \\ e-mail: kadekkevinseptian@gmail.com, krisna.heryanda@undiksha.ac.id
}

\begin{abstract}
Abstrak
Tujuan penelitian ini diantaranya agar mengetahui pengaruh (1) motivasi kerja serta disiplin kerja terhadap kinerja pegawai, (2) motivasi kerja pada kinerja pegawai, (3) disiplin kerja pada kinerja pegawai, dan (4) motivasi kerja pada disiplin kerja pegawai PT Pinus Merah Abadi Singaraja. Penelitian ini menggunakan rancangan kuantitatif kausal dengan pegawai PT Pinus Merah Abadi Singaraja sebagai subjek penelitian dan motivasi kerja,disiplin kerja serta kinerja pegawai sebagai objek penelitian. Populasi pada penelitian ini yakni pegawai PT Pinus Merah Abadi Singaraja sebanyak 32 orang. Data dikumpulkan melalui kuesioner serta menggunakan analisis jalur. Hasil penelitian memperlihatkan (1) motivasi kerja serta disiplin kerja memberi pengaruh positif pada kinerja pegawai, (2) motivasi kerja memberi pengaruh positif pada kinerja pegawai, (3) disiplin kerja memberi pengaruh positif pada kinerja pegawai, serta (4) motivasi kerja memberi pengaruh positif pada disiplin kerja pegawai.
\end{abstract}

Kata kunci: disiplin kerja, kinerja, motivasi kerja

\begin{abstract}
This research aimed at determining the effect of (1) work motivation and work discipline on employee performance, (2) work motivation on employee performance, (3) work discipline on employee performance, and (4) work motivation on employee work discipline at PT Pinus Merah Abadi Singaraja. This research's design is uses a causal quantitative. The subject of this research were employee off PT Pinus Merah Abadi Singaraja and the object of this research were work motivation, work discipline and employee performance. The population of this research were 32 people. The data were collected by using a questionnaire and it used path analysis. The results show (1) work motivation and work discipline have a positive effect toward employee's performance, (2) work motivation has a positive effect toward employee's performance, (3) work discipline has a positive effect toward employee's performance, and (4) work motivation has an positive effect toward employee's work discipline.
\end{abstract}

Keywords: performance, work discipline, work motivation

\section{Pendahuluan}

Sumber daya manusia (SDM) ialah aspek penting untuk dibesarkan guna menggapai tujuan organisasi. SDM yang bermutu serta sanggup penuhi tuntutan pekerjaan yang terus menjadi diperlukan. Tanpa pemahaman aspek yang satu ini, pencapaian akan tujuan dari organisasi akan terhambat. Manajemen perusahaan wajib mengupayakan semaksimal mungkin agar dapat memperdayakan SDM yang dipunyai buat menemukan motivasi, disiplin serta kinerja yang besar. Menurut Hasibuan (2003) manajemen SDM adalah sebuah bidang manajemen yang spesial menekuni ikatan serta peranan manajemen manusia dalam organisasi perusahaan. Suatu organisasi menyadari bahwa manusia dalam suatu perusahaan merupakan unsur yang dapat memberikan keunggulan bersaing. Tiap perusahaan hendak berupaya buat senantiasa tingkatkan kinerja karyawannya demi tercapainya tujuan yang sudah diresmikan perusahaan. Menurut Sinambela (2012) yang menyatakan kinerja karyawan sangat diperlukan, karena sebuah kinerja akan mengetahui bagaimana pengetahuan dan skill pekerja dalam memenuhi segala hal yang ditugaskan terhadapnya. Selain kemampuan serta keterampilan, pekerja juga harus memiliki motivasi kerja yang tinggi dan disiplin kerja yang baik. Seorang pekerja yang mempunyai inspirasi kerja yang tinggi di tempat kerja akan mempunyai tingkat disiplin kerja yang signifikan, mengingat dengan motivasi kerja yang tinggi 
pihak pekerja merasa didorong guna berfungsi dengan maksimal sehingga para pekerja tersebut akan mengikuti semua pedoman kerja yang ditetapkan oleh organisasi. Menurut Khadarisma (2012) mengatakan bahwa motivasi kerja merupakan salah satu faktor pendorong atau penggerak utama dalam diri seorang individu untuk dapat menjalankan dan bekerja secara efektif terkait kewajiban serta komitmen yang disepakati sebelumnya. Ketika pekerja berfungsi dengan baik dan menyetujui semua pedoman yang ditetapkan oleh organisasi, maka kinerja berikutnya akan maksimal.

Keberhasilan organisasi dalam mengelola SDM dapat diukur melalui kinerja karyawannya. Kinerja diduga dipengaruhi oleh motivasi kerja dan disiplin kerja karyawan, hal ini didukung oleh teori yang diungkapkan oleh Priyono (2010) yang menyatakan jika karyawan memiliki motivasi kerja yang tinggi serta disiplin kerja tinggi maka kinerja pegawai selalu berkembang. Teori tersebut juga dipertegas dengan hasil penelitian dari Rukhayati (2018) dalam penelitiannya menunjukkan hasil bahwa motivasi kerja serta disiplin kerja mempengaruhi kinerja karyawan secara positif.

PT Pinus Merah Abadi Cabang Singaraja merupakan sebuah perusahaan swasta yang berkecimpung dalam lingkup penjualan dan distribusi produk-produk berlisensi dari Nabati Group. Perusahaan tersebut menyalurkan serta mendistribusikan barang makanan melalui pabrikan (manufacturer) keberbagai toko atau pengecer yang berada di seluruh daerah kabupaten Buleleng. Berangkat dari penelitian awal ditemukan tingkat realisasi dan target terendah pada PT Pinus Merah Abadi Cabang Singaraja. Sebagai perbandingan selain PT Pinus Merah Abadi Cabang Singaraja ada pengusaha lainnya yang berkecimpung di lingkup yang sejenis yaitu PT Mayora Indah Tbk Cabang Singaraja dan PT Arta Boga Cemerlang Cabang Singaraja. Hal ini bisa dipertegas pada pada Tabel 1.1.

Tabel 1.1

Data Target dan Realisasi Penjualan pada Tiga Perusahaan yang sejenis Tahun 2019

\begin{tabular}{clcccc}
\hline No & Nama Perusahaan & Tahun & $\begin{array}{c}\text { Target } \\
\text { penjualan } \\
\text { (Box) }\end{array}$ & $\begin{array}{c}\text { Realisasi } \\
\text { penjualan } \\
\text { (Box) }\end{array}$ & Kategori \\
\hline 1 & $\begin{array}{l}\text { PT Pinus Merah Abadi } \\
\text { Singaraja }\end{array}$ & 2019 & 2.400 & 1.978 & $\begin{array}{c}\text { Belum } \\
\text { Tercapai }\end{array}$ \\
2 & $\begin{array}{l}\text { PT Mayora Indah Tbk } \\
\text { Singaraja }\end{array}$ & 2019 & 2.750 & 2.830 & Tercapai \\
3 & $\begin{array}{l}\text { PT Arta Boga } \\
\text { Cemerlang Singaraja }\end{array}$ & 2019 & 2.630 & 2.720 & Tercapai \\
\hline
\end{tabular}

Berdasarkan data pada Tabel 1.1 bisa diamati dimana PT Pinus Merah Abadi Singaraja belum mencapai target yang ditetapkan oleh perusahaan, sedangkan PT Mayora Indah Tbk Singaraja dan PT Arta Boga Cemerlang Singaraja sudah mencapai atau melebihi target penjualan yang telah disepakati bersama, oleh karena itu penelitian di fokuskan di PT Pinus Merah Abadi Singaraja. Disamping itu, pada observasi awal ditemukan bahwa kinerja pegawai pada PT Pinus Merah Abadi Singaraja masih belum mencapai standar kinerja yang ditentukan oleh perusahaan. Hal tersebut menunjukkan bahwa kinerja pegawai pada PT Pinus Merah Abadi Singaraja masih belum mencapai standar kinerja yang ditentukan oleh perusahaan. Dapat dilihat dari 10 pekerja yang menjadi responden awal belum mencapai kategori kinerja yang sesuai standar perusahaan. Selain permasalahan pada standar kinerja yang belum tercapai ditemukan juga permasalahan mengenai kerjasama pegawai. Berdasarkan observasi awal bahwa pekerja kurang memiliki kerjasama dalam bekerja, misalnya masih tingginya tingkat egoisme pegawai untuk diterima pendapat pribadinya tanpa memperhatikan atau menerima pendapat dari pegawai lain. Selain itu karyawan sering melimpahkan tugas atau pekerjaannya kepada pegawai lain. Masalah tersebut harus diperhstiksn oleh pimpinan perusahaan agar selalu menjaga dalam meningkatkan kinerja pegawainya. Memberi motivasi itu penting di setiap organisasi. Upaya yang dapat 
dilaksanakan oleh pihak perusahaan untuk memiliki opsi yang berdampak pada pelaksanaan pekerjanya.

Upaya yang dapat dilaksanakan oleh pihak perusahaan untuk memiliki opsi yang berdampak pada pelaksanaan pekerja adalah penataan motivasi kerja, karena motivasi dapat menunjang kepercayaan diri yang representatif sehingga dapat meningkatkan presentasi mereka. Upaya yang dapat diberikan yakni dengan pemberian motivasi yaitu berupa gaji pegawai yang sesuai. Gaji yang diterima oleh pegawai PT Pinus Merah Abadi Singaraja tidak sesuai dengan kebijakan dari pemerintah daerah pada Surat Keputusan (SK) Gubernur Bali Nomor 2235/03-G/HK/2019 tentang Upah Minimum Kabupaten/Kota (UMK) Kabupaten Buleleng Tahun 2019 di Provinsi Bali dimana UMK ditetapkan sebesar Rp. 2.338.850. Gaji yang diterima karyawan dirasa belum mampu memenuhi kebutuhan karyawan. Hal tersebut menyebabkan karyawan kurang maksimal dalam bekerja. Selain permasalahan pada gaji karyawan yang tidak sesuai dengan UMK ditemukan juga permasalahan mengenai rekan kerja seperti terjadi kesalahpahaman berkomunikasi dalam bekerja antara karyawan maupun atasan. Misalnya karyawan tidak sengaja berkata yang kurang sopan terhadap sesama rekan kerja sehingga dapat menyinggung karyawan lainnya sehingga membuat hubungan antara karyawan kurang harmonis. Hal tersebut akan membuat kondisi kerja yang tidak nyaman sehingga dapat terdampak kepada kinerja tidak maksimal. Motivasi kerja berkaitan erat dengan disiplin kerja, karena dengan motivasi yang dimiliki oleh pegawai maka pekerja tersebut akan bekerja dengan baik dan mengikuti semua peraturan yang ditetapkan oleh organisasi.

Disiplin kerja merupakan kesadaran dan kesediaan seseorang menaati semua peraturan perusahaan dan norma-norma sosial yang berlaku serta memiliki etika yang baik dalam bekerja. Ketika pegawai sudah memiliki disiplin yang baik maka pegawai tersebut selalu menerapkan aturan yang disepakati oleh organisasi. Selain permasalahan pada gaji karyawan yang tidak sesuai dengan UMK, permasalahan mengenai rekan kerja dan kondisi kerja ditemukan juga permasalahan mengenai disiplin kerja karyawan, berdasarkan hasil wawancara dengan Human Resource Departement (HRD) data yang diberikan mengenai absensi pegawai di PT Pinus Merah Abadi Singaraja terdapat masalah yaitu dari kehadiran waktu kerja, ketepatan karyawan terhadap waktu bekerja, dan ketaatan pekerja terhadap peraturan perusahaan serta tanggung jawab dalam menyelesaikan pekerjaan yang masih mengalami permasalahan, seperti ketepatan waktu bekerja pegawai menjadi permasalahan dilihat dari banyaknya pekerja yang datang terlambat saat masuk kerja, mangkir/keluar saat jam kerja, dan setelah istirahat selesai pekerja tidak langsung kembali bekerja serta pekerja diketahui sering pulang mendahului. Selain itu, ketidakdisiplinan pegawai juga dapat dilihat dari kelengkapan pada saat bekerja, seperti karyawan lupa dalam membawa faktur penjualan, Ketidakdisiplinan ini dapat dilihat dari sikap pegawai yang belum mampu sepenuhnya menerapkan semua aturan kerja yang berlaku di perusahaan. Rendahnya disiplin kerja karyawan pada PT Pinus Merah Abadi Singaraja dapat dilihat dari jumlah pegawai yang dijadikan observasi awal yaitu sebanyak 10 orang dengan batas toleransi pelanggaran 3 kali, namun kenyataannya tingkat pelanggaran rata-rata yang dilakukan oleh pekerja sebanyak 7 kali, pelanggaran paling sering dilakukan oleh pegawai adalah datang terlambat, pulang mendahului dan kurang disiplin dalam membawa perlengkapan. Apabila ini terus berlanjut maka dikhawatirkan setiap individu semakin tidak disiplin dan kinerjanya menurun sehingga akan berdampak pada kinerja organisasi secara keseluruhan. Berdasarkan fakta-fakta masalah yang ditemukan pada PT Pinus Merah Abadi Singaraja, tidak tercapainya standar kinerja pegawai diduga disebabkan oleh motivasi kerja dan disiplin kerja pegawai yang rendah. Hal tersebut tidak sejalan dengan teori yang dikemukakan oleh Priyono (2010) menyatakan bahwa jika pegawai memiliki motivasi kerja yang tinggi dan disiplin kerja tinggi maka kinerja pegawai akan meningkat. Teori tersebut juga dipertegas dengan hasil penelitian empirik dari Rukhayati (2018) dalam penelitiannya mendapatkan hasil yakni motivasi kerja dan disiplin kerja berpengaruh positif dan signifikan terhadap kinerja pegawai. Melihat kesenjangan fakta masalah dengan harapan teori maka dipandang perlu dilakukan penelitian untuk meningkatkan kinerja pegawai pada PT Pinus Merah Abadi Singaraja dengan judul 
"Pengaruh Motivasi Kerja dan Disiplin Kerja terhadap Kinerja Karyawan pada PT Pinus Merah Abadi Singaraja". Tujuan dari penelitian ini yakni menguji pengaruh, motivasi kerja serta disiplin kerja terhadap kinerja karyawan, motivasi kerja terhadap disiplin kerja, motivasi kerja terhadap kinerja karyawan serta disiplin kerja terhadap kinerja karyawan pada PT Pinus Merah Abadi Singaraja.

Hubungan motivasi kerja dan disiplin kerja terhadap kinerja pegawai dikemukakan oleh Priyono (2010) yang berpendapat jika pegawai memiliki motivasi kerja yang tinggi dan disiplin kerja tinggi maka kinerja pegawai akan meningkat. Terdapat pengaruh motivasi kerja serta disiplin kerja terhadap kinerja pegawai didukung oleh penelitian empirik dari Rukhayati (2018) yang menunjukkan hasil bahwa motivasi kerja dan disiplin kerja mempengaruhi kinerja karyawan secara positif. Dengan demikian motivasi kerja dan disiplin kerja mempengaruhi kinerja pegawai secara positif. Hubungan motivasi kerja terhadap disiplin kerja pegawai didukung oleh teori Sinungan (2003) menyatakan motivasi yang tinggi akan membuat pegawai bekerja keras sehingga mendorong para pekerja untuk bekerja dengan baik sehingga disiplin kerja pegawai tersebut tinggi. Hal tersebut didukung oleh teori yang dikemukakan Hasibuan (2012) yang menyatakan jika motivasi kerja pegawai tinggi maka pegawai tersebut akan memiliki disiplin kerja yang tinggi pula. Hal tersebut dipertegas oleh penelitian empirik dari Rukhayati (2018) dalam penelitiannya terdapat hasil seperti motivasi kerja mempengaruhi disiplin kerja secara positif. Dengan demikian motivasi kerja berpengaruh positif terhadap disiplin kerja pegawai. Hubungan motivasi kerja terhadap kinerja pegawai diungkapkan Rivai (2011) yang menunjukkan semakin tinggi motivasi kerja pegawai maka kinerja pegawai akan semakin tinggi pula. Hal ini dipertegas oleh penelitian empirik yang dilakukan oleh Muhammad (2017) yang menunjukkan hasil bahwa motivasi kerja mempengaruhi kinerja pegawai secara positif. Dengan demikian bisa mendapat kesimpulan seperti motivasi kerja mempengaruhi kinerja karyawan secara positif. Hubungan disiplin kerja terhadap kinerja karyawan dikemukakan oleh Hasibuan (2013) tentang disiplin kerja karyawan adalah dimana jika seorang karyawan menunjukkan sikap yang baik terhadap perusahaan tempat dia bekerja, seperti bertanggungjawab dengan tugas yang diberikan oleh perusahaan, tidak lalai dengan waktu kerja, mematuhi norma yang disepakati perusahaan, lalu mendukung program perusahaan agar dapat meningkatkan kualitas serta kuantitas produk. Hal ini didukung oleh teori Hasibuan (2006) Semakin baik disiplin kerja seseorang, maka semakin tinggi hasil kinerja yang akan dicapai. Hal ini didukung oleh penelitian yang dilakukan oleh Syafrina (2017) seperti pendapatnya adalah bahwa disiplin kerja mempengatuhi kinerja pegawai secara positif. Penelitian tersebut sepemikiran dengan penelitian Rukhayati (2018) dalam penelitiannya menunjukan hasil bahwa disiplin kerja mempengaruhi kinerja pegawai secara positif. Dengan demikian dapat disimpulkan bahwa disiplin kerja mempengaruhi kinerja karyawan secara positif.

\section{Metode}

Pengujian ini bertujuan untuk mendapatkan gambaran secara garis besar dampak motivasi kerja dan disiplin kerja terhadap kinerja pegawai pada PT Pinus Merah Abadi Singaraja. Ada tiga faktor yang digunakan dalam pengujian ini, khususnya dua faktor bebas dan satu faktor terikat. Variabel otonom pengujian ini yakni motivasi kerja $\left(X_{1}\right)$ dan disiplin kerja $\left(\mathrm{X}_{2}\right)$, sedangkan variabel yang diandalkan dalam pengujian ini yakni kinerja pegawai $(\mathrm{Y})$.

Rancangan penelitian ini yakni penelitian kuantitatif kausal. Khususnya penelitian yang bermaksud untuk menunjukkan hubungan sebab akibat atau pada akhirnya memecah bagaimana suatu variabel mempengaruhi faktor-faktor yang berbeda. Tahap dalam penelitian kuantitatif kausal yakni (1) masalah figuring, (2) spekulasi survei, (3) teori perencanaan, (4) pengumpulan informasi dan (5) mencapai kesimpulan.

Subjek dalam penelitian ini adalah pegawai PT Pinus Merah Abadi Singaraja, serta objek penelitian ini yaitu motivasi kerja, disiplin kerja dan kinerja pegawai. Populasi merupakan wilayah generalisasi yang terdiri atas subjek yang mempunyai kualitas dan karakteristik tertentu yang ditetapkan untuk dipelajari dan kemudian ditarik kesimpulannya (Sugiyono, 2014). Populasi dalam penelitian ini adalah seluruh pegawai PT Pinus Merah 
Abadi Singaraja yakni berjumlah 32 orang. Penelitian ini tergolong penelitian populasi karena semua populasi digunakan sebagai responden penelitian. Hal ini didukung oleh pendapat Arikunto dalam Syafrina (2017) yang menyatakan apabila subjek penelitian kurang dari 100, maka lebih baik diambil semua sehingga penelitian ini merupakan penelitian populasi.

Jenis data yang digunakan yakni data kuantitatif. Data kuantitatif yaitu data yang bersifat terstruktur berupa angka-angka yang diperoleh dari PT Pinus Merah Abadi Singaraja. Jenis data yang dibutuhkan yakni data primer seperti data disiplin kerja, motivasi kerja, dan kinerja karyawan. Sumber data yang digunakan dalam penelitian ini yakni berasal dari data primer yaitu data yang diperoleh secara langsung dari sumber pertama individu maupun perseorangan seperti hasil pengisian kuesioner (Umar, 2007). Data primer yang diperoleh berasal dari pegawai yang penilaiannya dilakukan oleh pimpinan PT Pinus Merah Abadi Singaraja. Metode pengumpulan data yang digunakan yakni kuesioner. Kuesioner merupakan cara pengumpulan data dengan menyiapkan daftar pertanyaan-pertanyaan yang terstruktur yang diberikan kepada responden untuk dijawab sesuai dengan variabel yang diteliti (Sugiyono, 2011). Kuesioner bersifat untuk mendapatkan data mengenai motivasi kerja, disiplin kerja dan kinerja pegawai.

Analisis jalur merupakan pengembangan analisis regresi berganda yang menguraikan besaran pengaruh dari variabel bebas terhadap variabel terikat secara langsung maupun tidak langsung (Irianto, 2012). Analisis jalur yang digunakan untuk memperoleh besarnya pengaruh total dan pengaruh langsung serta tidak langsung dari variabel motivasi kerja dan disiplin kerja terhadap kinerja pegawai pada PT Pinus Merah Abadi Singaraja. Teknik analisis data yang digunakan yaitu analisis jalur. Urutan pengolahan dan analisis data dalam analisis jalur yakni: (1) menyebar kuesioner, (2) tabulasi data kuesioner, (3) ambil data ordinal hasil kuesioner, (4) mengubah data ordinal menjadi data interval, (5) memasukkan total jumlah per variabel pada sistem SPSS untuk diuji, dan (6) Menginterfretasikan hasil uji yang sudah diperoleh.

\section{Hasil dan Pembahasan}

Deskripsi data penelitian mencakup hasil analisis deskripsi yang akan disajikan data mengenai variabel motivasi kerja, disiplin kerja dan kinerja pegawai dapat dilihat pada tabel 1.1 .

Tabel 1.1

Hasil Analisis Deskripsi Data

\begin{tabular}{clcc}
\hline No & \multicolumn{1}{c}{ Variabel } & Total Jawaban Responden & Kategori \\
\hline 1 & Motivasi Kerja & 685 & Tinggi \\
2 & Disiplin Kerja & 670 & Tinggi \\
3 & Kinerja Karyawan & 846 & Tinggi \\
\hline
\end{tabular}

Hasil analisis deskripsi data memperlihatkan bahwa variabel motivasi kerja, disiplin kerja dan kinerja pegawai berada dalam kategori tinggi sehingga perlu ditingkatkan sehingga mencapai kategori sangat tinggi. Adapun hasil pengujian hipotesis dengan analisis jalur pada pengaruh motivasi kerja dan disiplin kerja terhadap kinerja karyawan tampak pada Tabel 1.2

Tabel 1.2

Hasil Penelitian PengaruhVariabel Motivasi Kerja $\left(X_{1}\right)$ dan Disiplin Kerja $\left(X_{2}\right)$ Terhadap Kinerja Karyawan (Y)

\begin{tabular}{lcccc}
\hline Parameter & Koefisien & $\alpha$ & $p$-value & Keputusan \\
\hline Ryx $_{1} \mathrm{x}_{2}$ & 0,815 & 0,05 & 0,000 & MenolakH \\
$\mathrm{R}^{2} \mathrm{yx}_{1} \mathrm{x}_{2}$ & 0,664 & 0,05 & 0,000 & - \\
$\mathrm{Px}_{2} \mathrm{x}_{1}$ & 0,659 & 0,05 & 0,019 & MenolakH \\
$\mathrm{P}^{2} \mathrm{x}_{2} \mathrm{x}_{1}$ & 0,434 & 0,05 & 0,000 & -
\end{tabular}




\begin{tabular}{lcccc}
\hline Parameter & Koefisien & $\alpha$ & $p$-value & Keputusan \\
\hline $\mathrm{Pyx}_{1}$ & 0,439 & 0,05 & 0,013 & MenolakH \\
$\mathrm{P}^{2} \mathrm{yx}_{1}$ & 0,193 & 0,05 & 0,000 & - \\
$\mathrm{Pyx}_{2}$ & 0,455 & 0,05 & 0,000 & MenolakH \\
$\mathrm{P}^{2} \mathrm{yx}_{2}$ & 0,207 & 0,05 & 0,000 & - \\
$\mathrm{Px}_{2} \varepsilon_{1}$ & 0,566 & - & - & - \\
$\mathrm{Py}_{2}$ & 0,336 & - & - & - \\
\hline
\end{tabular}

Pengaruh masing-masing variabel motivasi kerja, disiplin kerja terhadap kinerja karyawan pada PT Pinus Merah Abadi Singaraja dapat digambarkan pada Gambar 1.1.

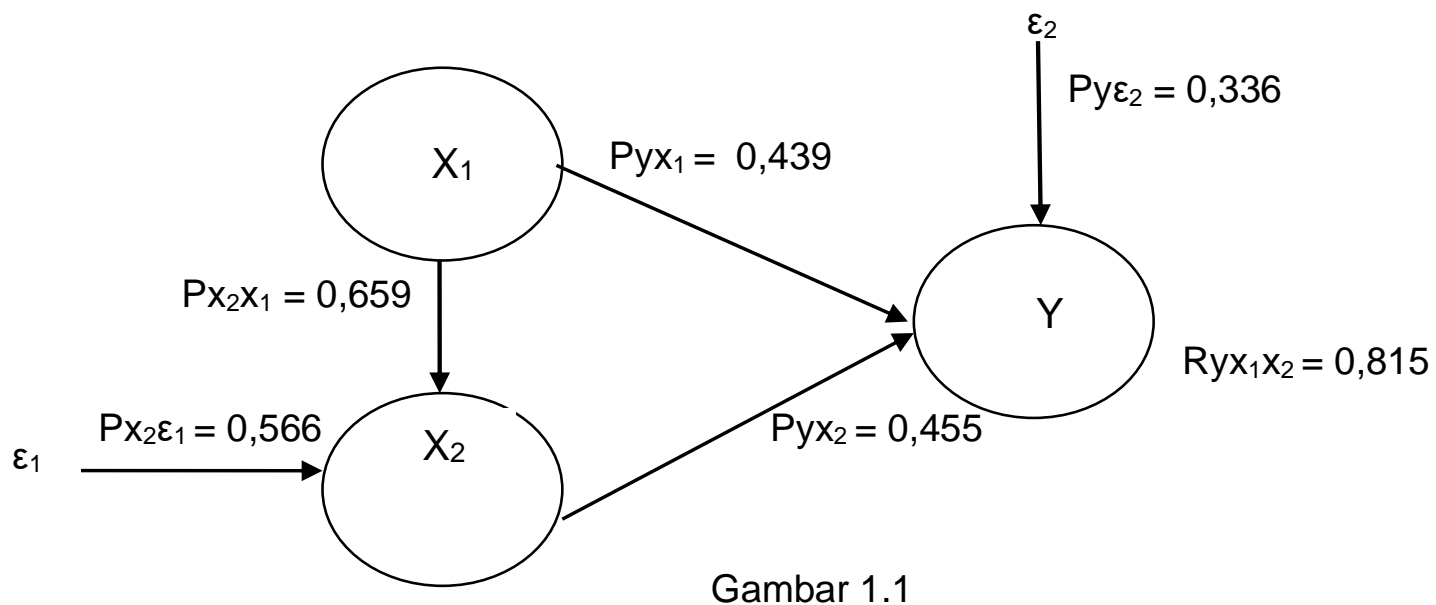

Struktur Pengaruh Variabel Motivasi Kerja dan Disiplin Kerja Terhadap Kinerja Karyawan

Besar sumbangan pengaruh langsung dan tidak langsung dari variabel motivasi kerja dan disiplin kerja terhadap kinerja karyawan dalam penelitian ini dapat dilihat pada Tabel 1.3.

Tabel 1.3

Sumbangan Pengaruh Variabel Motivasi Kerja $\left(\mathrm{X}_{1}\right)$ dan Disiplin Kerja $\left(\mathrm{X}_{2}\right)$ terhadap Kinerja Karyawan $(\mathrm{Y})$

\begin{tabular}{lcc}
\hline Keterangan & Besar Sumbangan & Persentase \\
\hline $\begin{array}{l}\text { Besar pengaruh } X_{1} \text { secara langsung terhadap } \\
\text { Y }\end{array}$ & 0,193 & $19,3 \%$ \\
Besar pengaruh $X_{1}$ secara tidak langsung & 0,132 & $13,2 \%$ \\
melalui $X_{2}$ terhadap $Y$ & & \\
Besar pengaruh total $X_{1}$ terhadap $Y$ & 0,325 & $32,5 \%$ \\
Besar pengaruh $X_{2}$ secara langsung terhadap & 0,207 & $20,7 \%$ \\
$Y$ & & \\
Besar pengaruh total $X_{1}$ dan $X_{2}$ terhadap $Y$ & 0,532 & $53,2 \%$ \\
Besar pengaruh faktor lain terhadap $Y$ & 0,336 & $33,6 \%$ \\
Total & 1,000 & $100,0 \%$ \\
\hline
\end{tabular}

Data pada Tabel 1.3 menunjukkan bahwa ada pengaruh $\mathrm{X} 1$ dan $\mathrm{X} 2$ terhadap $\mathrm{Y}$ secara simultan berpengaruh positif terhadap Y pada PT Pinus Merah Abadi Singaraja. Hal tersebut ditunjukkan dengan $p$-value $\mathrm{Ryx}_{1} \mathrm{x}_{2}=0,000<\alpha=0,05$. Besar sumbangan pengaruh secara simultan dari $X 1$ dan $X 2$ terhadap $Y$ yakni 0,664 . Hasil tersebut menunjukkan bahwa sebesar $66,4 \% \mathrm{Y}$ dipengaruhi oleh variabel $\mathrm{X} 1$ dan $\mathrm{X} 2$, sedangkan pengaruh dari variabel lain terhadap $Y$ adalah $33,6 \%$. Data pada Tabel 1.3 menunjukkan bahwa ada pengaruh $X 1$ terhadap $\mathrm{X} 2$. Hal tersebut ditunjukkan dengan $p$-value $\mathrm{Px}_{2} \mathrm{X}_{1}=0,000<\alpha(0,05)$ dengan besar 
sumbangan pengaruh dari $\mathrm{X} 1$ terhadap $\mathrm{X} 2$ yakni 0,434 . Hal tersebut menunjukkan bahwa sebesar $43,4 \%$ X2 dipengaruhi oleh X1, sisanya $56,6 \%$ dipengaruhi oleh variabel lain yang tidak diteliti dalam penelitian ini. Data hasil penelitian pada Tabel 1.3 menunjukkan bahwa ada pengaruh $\mathrm{X} 1$ terhadap $\mathrm{Y}$. Keeratan hubungan pengaruh dari $\mathrm{X} 1$ terhadap $\mathrm{Y}$ sebesar 0,439 artinya $43,9 \% \mathrm{Y}$ dipengaruhi oleh $\mathrm{X} 1$ dan besar sumbangan pengaruh $\mathrm{X} 1$ terhadap $\mathrm{Y}$ yakni $19,3 \%$ dengan $p$-value $\mathrm{Pyx}_{1}=0,000<\alpha=0,05$. Hal ini menunjukan bahwa $\mathrm{X} 1$ berpengaruh secara positif terhadap Y. Artinya, jika X1 tinggi ,maka Y juga akan semakin tinggi. Data pada Tabel 1.3 dapat dijelaskan bahwa ada pengaruh dari $\mathrm{X} 2$ terhadap $\mathrm{Y}$. Keeratan hubungan pengaruh $\mathrm{X} 2$ terhadap $\mathrm{Y}$ sebesar 0,455 artinya $45,5 \% \mathrm{Y}$ dipengaruhi oleh $\mathrm{X} 2$, dan besar sumbangan pengaruh dari $X 2$ terhadap $Y$ yakni $20,7 \%$ dengan $p$-value $\operatorname{Pyx}_{2}=0,000<\alpha=0,05$. Hal ini menunjukan bahwa $X 2$ berpengaruh secara positif terhadap $Y$. Artinya jika $X 2$ tinggi,maka $Y$ juga akan semakin tinggi.

Berdasarkan penelitian yang dilakukan bahwa ada pengaruh X1 dan X2 secara bersama-sama berpengaruh terhadap Y. Hasil penelitian ini sesuai dengan teori dari Priyono (2010) yang menyatakan jika motivasi kerja karyawan tinggi dan disiplin kerja tinggi maka kinerja karyawan akan meningkat. Karyawan yang memiliki motivasi kerja yang tinggi dan disiplin kerja yang tinggi cenderung akan mendorong pegawai untuk melakukan pekerjaan dengan baik sehingga akan meningkatkan kinerjanya. Hasil penelitian ini mendukung kajian empirik dari Rukhayati (2018) yang menunjukkan hasil bahwa motivasi kerja dan disiplin kerja berpengaruh positif dan signifikan terhadap kinerja pegawai.

Penelitian mengenai pengaruh $\mathrm{X} 1$ dan $\mathrm{X} 2$ dimana $\mathrm{X} 1$ secara positif berpengaruh signifikan terhadap X2. Hal ini sesuai dengan teori yang dikemukakan oleh Hasibuan (2012) yang menyatakan jika motivasi kerja karyawan tinggi maka karyawan tersebut akan memiliki disiplin kerja yang tinggi pula. Untuk dapat meningkatkan motivasi kerja pegawai PT Pinus Merah Abadi Singaraja maka diperlukan motivasi dari pihak atasan untuk mendorong pegawainya agar bekerja dengan baik dan mengikuti semua aturan yang ditetapkan oleh perusahaan. Hasil penelitian ini mendukung kajian empirik dari Rukhayati (2018) dalam penelitiannya menunjukkan hasil bahwa motivasi kerja berpengaruh positif terhadap disiplin kerja. Hasil penelitian menunjukkan bahwa disiplin kerja berpengaruh secara positif terhadap kinerja pegawai pada PT Pinus Merah Abadi Singaraja. Hasil penelitian ini sesuai dengan teori Hasibuan (2006) Semakin baik disiplin kerja seseorang, maka semakin tinggi hasil kinerja yang akan dicapai. Dengan disiplin yang baik maka pegawai akan bekerja sesuai dengan aturan yang ditetapkan oleh PT Pinus Merah Abadi Singaraja.

Penelitian mengenai pengaruh $\mathrm{X} 1$ terhadap $\mathrm{Y}$. Hasil penelitian ini sejalan dengan teori Rivai (2011) yang menunjukkan semakin tinggi motivasi kerja pegawai maka kinerja pegawai akan semakin tinggi. Dengan motivasi kerja yang tinggi yang dimiliki oleh pegawai maka pegawai tersebut akan terdorong dan memiliki rasa semangat dalam bekerja, ketika pegawai sudah memiliki dorongan dan semangat kerja maka pegawai akan bekerja dengan baik sehingga akan menghasilkan kinerja yang maksimal. Penelitian ini mendukung kajian empirik dari Muhammad (2017) yang menunjukkan hasil bahwa motivasi kerja berpengaruh positif terhadap kinerja karyawan. Berdasarkan pengamatan dilapangan, pemberian motivasi karyawan pada PT Pinus Merah Abadi Singaraja dikatakan kurang, dilihat dari sikap atasan yang kurang memberikan dorongan kepada karyawannya. Sikap yang kurang bersahabat dengan bawahannya, menyebabkan karyawan kurang termotivasi untuk meningkatkan kinerjanya. Selain sikap dari atasan, faktor lingkungan kerja fisik yang kurang nyaman, sehingga karyawan merasa kurang nyaman saat bekerja.

Berdasarkan hasil penelitian menunjukkan bahwa $X 1$ memberikan sumbangan pengaruh yang lebih besar terhadap $\mathrm{Y}$ melalui $\mathrm{X} 2$ dibandingkan dengan besar sumbangan langsung dari $x 1$ terhadap Y. Sehingga PT Pinus Merah Abadi Singaraja hendaknya mempertimbangkan untuk menciptakan motivasi kerja melalui peningkatan disiplin kerja pegawai, karena hal ini akan memberikan dampak yang lebih besar kepada kinerja pegawai dibandingkan dengan meningkatkan kinerja secara langsung tanpa melalui disiplin kerja. Hambatan dari penelitian ini adalah persepsi hanya dilakukan dalam satu organisasi, sehingga konsekuensi dari penelitian ini tidak bisa diringkas ke organisasi yang berbeda. 
Begitu pula,mengingat jumlah populasi yang digunakan dalam penelitian ini masih terbatas, diyakini para analisis yang berbeda akan memanfaatkan organisasi yang lebih besar dengan populasi penelitian yang lebih luas sehingga hasil penelitian lebih dapat diandalkan.

\section{Simpulan dan Saran}

Merujuk pada hasil penelitian dan pembahasan diatas, bisa ditarik beberapa simpulan bahwasanya (1) Motivasi kerja dan disiplin kerja memberi pengaruh positif terhadap kinerja pegawai pada PT Pinus Merah Abadi Singaraja, (2) Motivasi kerja memberi pengaruh positif terhadap disiplin kerja pada PT Pinus Merah Abadi Singaraja, (3) Motivasi kerja memberi pengaruh positif terhadap kinerja pegawai pada PT Pinus Merah Abadi Singaraja, (4) Disiplin kerja memberi pengaruh positif terhadap kinerja pegawai pada PT Pinus Merah Abadi Singaraja.

Adapun saran yang bisa disampaikan diantaranya: (1) Bagi perusahaan, diharapkan agar lebih meningkatkan kinerja pegawai melalui motivasi kerja dan disiplin kerja karena penelitian membuktikan bahwa motivasi kerja dan disiplin kerja dapat mempengaruhi kinerja pegawai. Adapun cara yang dapat dilakukan untuk meningkatkan kinerja melalui motivasi kerja, yaitu: (a) memberikan motivasi kerja kepada setiap pegawai sehingga bisa lebih bersemangat dan giat dalam bekerja seperti bersikap lebih baik, dan (b) memperhatikan besar gaji yang diterima oleh pegawai agar sesuai dengan UMK. Disamping motivasi kerja disiplin kerja juga harus diperhatikan dengan cara memberikan nasihat kepada pegawai yang melakukan pelanggaran dan memberikan pemahaman mengenai aturan yang harus ditaati saat bekerja. Disamping itu PT Pinus Merah Abadi Singaraja harus memberikan kesempatan kepada para karyawan untuk mengembangkan keterampilan dan keahlian yang dimilikinya, sehingga dapat memberikan ruang kreativitas pada karyawan untuk mendorong kinerja yang maksimal. (2) Bagi peneliti yang tertarik untuk memeriksa bagian-bagian komparatif sehubungan dengan motivasi kerja, disiplin kerja, dan pelaksanaan yang representative diperlukan untuk membangun eksplorasi ini dengan menggunakan subjek pemeriksaan yang lebih luas. Terlebih lagi, juga diharapkan untuk menguji faktor-faktor lain yang secara tegas diduga mempengaruhi pelaksanaan yang repsentatif, misalnya kompensasi, lingkungan kerja, dan promosi jabatan.

\section{Daftar Pustaka}

Hasibuan, H. Malayu. 2013. Manajemen Sumber Daya Manusia Ed. Revisi. :Jakarta: Bumi Aksara

Kadarisman, M. 2012. Manajemen Pengembangan Sumber Daya Manusia. Jakarta : Rajawali Pers.

Muhammad, Ashari. 2017. Pengaruh Motivasi Dan Disiplin Kerja Terhadap Kinerja Karyawan Pada Pt PIn (Persero) Unit Pelayanan Transmisi Sulselrabar. Skripsi. Fakultas Ekonomi dan Bisnis, Universitas Islam Negeri Alauddin.

Priyono. 2010. Sumber Daya Manusia. Sidoarjo: Zifatama Publisher.

Rivai, Veithzal. 2011. Manajemen Sumber Daya Manusia Untuk Perusahaan. Edisi Kedua. Jakarta: PT. Raja Grafindo Persada.

Rukhayati, 2018. Pengaruh Motivasi dan Disiplin Kerja Terhadap Kinerja Karyawan di Puskesmas Talise. Vol 5, No. 2

Sinambela, Lijan Poltak. 2012. Kinerja Pegawai Teori Pengukuran dan Implikasi. Yogyakarta: Graha Ilmu.

Sinungan, Muchdarsyah. 2003. Produktivitas Apa dan Bagaimana. Bandung: Bumi Aksara.

Sugiyono. 2014. Statistika Untuk penelitian. Bandung: CV Alfabeta.

Syafrina, Nova. 2017. Pengaruh Disiplin Kerja terhadap Kinerja karyawan pada PT. Suka Fajar Pekanbaru. Sekolah Tinggi Ilmu Ekonomi Riau. 
Umar, Husein. 2007. Metode Penelitian Untuk Skripsi Dan Tesis Bisnis. Jakarta: PT. Raja Grafindo Persada. 